\title{
BLOOD DESCRIPTION, PARASITE INFESTATION AND SURVIVAL RATE OF CARP (Cyprinus carpio) WHICH IS EXPOSED BY SPORE PROTEIN Myxobolus koi ON REARING POND AS IMMUNOSTIMULAN MATERIAL
}

\author{
Laode Abdul Syafar ${ }^{1}$, Gunanti Mahasri ${ }^{2}$, Fedik Abdul Rantam ${ }^{3}$ \\ ${ }^{1}$ Mahasiswa Program Studi S2 Bioteknologi Perikanan dan Kelautan, Sekolah Pasca Sarjana \\ Universitas Airlangga \\ ${ }^{2}$ Sekolah Pasca Sarjana, Universitas Airlangga \\ ${ }^{3}$ Fakultas Kedokteran Hewan, Universitas Airlangga \\ Email : laode_syafar@yahoo.co.id
}

\begin{abstract}
This research is an experimental research to determine the effect of spore protein Myxobolus koi on grass carp (Cyprinus carpio) in rearing pond. The sample used is grass carp (Cyprinus carpio) 90 fish $(10-15 \mathrm{~cm})$. Spore protein used in this research is Myxobolus koi spore protein, that has been found by predecessor researchers and has been tested in laboratory as immunostimulan. The exposure was done orally, mixed in the feed, with a dose of $2 \mu \mathrm{g} /$ gram dose of protein, feeded 1 time before being reared for 30 days. Parameters measured were: (1) leucocytes description (differentiated leucocytes of carp, (2) Parasitic infestation in carp and (3) Survival Rate / SR of carp were reared on pond for 30 days. The collected data is analyzed descriptively.

The results showed that there was alteration of leukocytes description (differential leukocytes) in carp (Cyprinus carpio) as an indicator of the immune response. A leukocyte differential examination showed that exposure to the Myxobolus koi spore protein, The highest total lymphocytes occurred in carp exposed to Myxobolus koi spores protein and reared from pond in Mojokerto, were $77.6 \%$, Monocytes of $16.3 \%$, Heterophyll $14.4 \%$, Eosinophils $7.6 \%$ and Basofil $0.4 \%$. The highest infestation of Myxobolus koi occurred in fish that was not exposed to spore protein was $53.33 \%$ after 30 days of reared at pond, while parasitic infestation in fish exposed to spore protein was only $16.66 \%$. Survival rate of carp indicated that the highest occurred in carp that exposed with spore protein and reared from pond in Mojokerto, equal to $90 \%$.

Myxobolus koi spore protein exposure given orally can makes alteration of leukocytes description (differential leukocytes), Decreased parasite infestation and increased survival of carp fish reared for 30 days, with the result that Myxobolus koi spore protein can be developed as an immunostimulant material.
\end{abstract}

Keyword: Myxobolus koi, Cyprinus carpio, spore protein, immunostimulant, infestation 


\section{PENDAHULUAN}

\subsection{Latar belakang}

Ikan mas (Cyprinus carpio) adalah merupakan salah satu spesies ikan air tawar yang mempunyai peluang pengembangan budidaya besar untuk meraih potensi pasar yang terus meningkat. Berdasarkan data dari Kementrian Perikanan dan Kelautan, dinyatakan bahwa produksi ikan mas di Indomesia mencapai berturut-turut dari tahun 2010 sampai dengan tahun 2014 adalah $267.100, \quad 280.400, \quad 300.000, \quad 325.000$ dan 350.000 ton (Subiyakto, 2014). Disamping itu ikan merupakan sumber protein hewani untuk memenuhi gizi masyarakat Indonesia (Sutanmuda, 2007).. Selanjutnya juga dikatakan mas merupakan jenis ikan konsumsi air tawar, di Indonesia telah dibudidayakan sejak tahun 1920. Budidaya ikan mas dilakukan di kolam biasa, di sawah, waduk, sungai air deras, maupun dalam keramba di perairan umum.

Banyak kendala yang dapat mempengaruhi tingkat keberhasilan budidaya ikan mas dimana kendala utama yang perlu diperhatikan adalah munculnya serangan penyakit. Umumnya penyakit yang sering ditemukan menyerang ikan mas dapat disebabkan oleh parasit, bakteri, virus maupun jamur (Anshery, 2008). Selanjutnya dikatakan bahwa penyakit tersebut dapat menyebabkan kerugian hingga $80 \%$ bahkan dapat mencapai $100 \%$ pada stadia benih (Mahasri, 2007). Salah satu penyakit yang sering menyerang pada ikan Mas adalah Myxobolusis yang disebabkan oleh Myxobolus koi. Umumnya penyakit ini ditemukan pada benih ikan Cyprinidae dan dapat menimbulkan kerugian hingga 100\% (Mahasri, 2013). Tahun 2002 telah terjadi kematian masal ikan mas di daerah Sleman dan Kulon Progo yang disebabkan oleh parasit Myxobolus sp dan Henneguya (Titis, dkk, 2009) sehingga kerugian yang dialami pembudidaya ikan cukup besar. Myxobolus sp juga ditemukan di daerah Ngrajek kabupaten Magelang pada tahun 2006 dengan prevalensi mencapai 91\%, (Obing, 2006). Kemudian di kolam ikan mas koi di Blitar prevalensi mencapai $86 \%$ pada tahun 2010 (Anugrahi, 2010).
Infeksi Myxobolus pada ikan mas dapat diketahui dengan gejala klinis yang khas itu terdapatnya nodul pada insang ikan mas (Cyprinus carpio), dalam jumlah yang dapat menyebabkan ikan sulit bernafas yang pada akhirnya dapat menyebabkan kematian (Yuasa et al., 2005). Untuk itu sangat perlu diketahui proses atau jalannya penyakit tersebut (patogenesis) agar dapat dideteksi secara dini, sehingga kematian dapat dicegah. Untuk meningkatkan pertahanan tubuh pada ikan mas terutama terhadap myxobolusis, perlu dicarikan bahan yang dapat dikembangkan sebagai imunostimuan.

Upaya peningkatan pertahanan tubuh pada ikan dapat dilakukan dengan imunisasi, dengan imunostimulan yang dapat diproduksi dari berbagai bahan dari alam maupun sintetis. Salah satu bahan yang dapat dikembangkan sebagai imunostimulan adalah protein dari patogen yang dapat menyebabkan penyakit pada ikan. Salah satu bahan tersebut adalah protein spora spora Myxobolus koi. Upaya pencegahan penyakit yang sudah banyak dilakukan umumnya dengan menggunakan bahan kimia atau antibiotik, akan tetapi al ini dapat menyebabkan adanya dampak negatif yaitu terjadinya resistensi dan terdapatnya residu di dalam tubuh ikan (Mahasri, 2007). Pencegahan penyakit ikan dengan menggunakan imunostimulan sudah mulai dikembangkan. Clark et al. (1996) berhasil mengisolasi protein membran antigen dari Paramecium, Tetrahymena dan Ichthyiophthirius multifiliis, diduga protein ini berperan dalam infestasi parasit pada inang. Selanjutnya dikatakan bahwa protein mayor merupakan ligan perlekatan yang penting pada Ichthyiophthirius multifiliis dan merupakan jembatan masuknya parasit ke dalam sel.

Wang dan Dickerson (2002) mengatakan bahwa surface immobilization antigen dari Ichthyophthyrius multifiliis dapat meningkatkan pertahanan tubuh pada Channel Catfish (Ichtalurus punctatus). Lin et al. (1996), memperkuat pernyataan Wang dan Dickerson, bahwa imunisasi pasif dari Ichthyophthirius multifiliis (Ciliata pathogen) dengan Murine Antibodi Monoklonal dapat meningkatkan ketahanan tubuh Channel Catfish. Imunisasi dengan protein membran antigen Ichthyophthirius multifiliis stadia theront dengan beberapa serotipe juga telah 
dilakukan oleh Leff, et al. (1994), Maki dan Dickerson (2003) dan Lin, et al. (1996) pada Channel Catfish dan berhasil menekan infestasi parasit.

Yusuf (2015) telah menganilisis respon imun ikan mas koki yang dipapar dengan whole protein spora Myxobolus koi yang dinyatakan terjadi peningkatan dan dapat meningtkatkan kelulushidupan secara laboratoris. Sementara hasil penelitian Woro (2015) menunjukkan bahwa crude protein spora Myxobolus koi juga dapat meningkatkan kelulushidupan dan respon imun ikan koi. Protein spora yang masuk ke dalam tubuh.

Yusuf (2015) mengatakan bahwa, pemaparan protein spora Myxobolus koi sebagai kandidat vaksin myxobolusis dapat dilakukan dengan pengamatan differensial leukosit terutama limfosit Tingkat kelulus hidupan ikan, efektivitas vaksin dianggap baik apabila nilai $\mathrm{SR} \geq 50 \%$. Hasil penelitiannya juga menunjukkan bahwa respon imun dan kelulushidupan (SR) ikan koi yang dipapar protein spora Myxobolus koi mengalami peningkatan. Selanjutnya dikatakan bahwa protein spora yang masuk ke dalam tubuh ikan mas akan ditangkap oleh reseptor pada sel $\mathrm{T}$ helper (2), dan sel T helper (2), kemudian akan mensekresikan sitokin yaitu IL-2, IL- 4, dan IL-6 sehingga meningkatkan jumlah limfosit dalam darah yang bertujuan untuk diferensiasi dan proliferasi sel lymphosit B. Diferensiasi sel lymphosit B akan menghasilkan sel plasma dan sel memori.

Penggunaan air dari kolam pemeliharaan ikan mas yang di lapang, dikarenakan secara alami banyak parasit yang hidup normal di perairan dan akan menjadi patogen bila lingkungan mendukung. Hal ini sesuai dengan hasil penelitian dari Mahasri (2007) yang menyatakan bahwa bebrapa protozoa akan meningkat aktivitas dan meningkat patogenitasnya pada kondisi bahan organik yang tinggi, oksigen yang rendah dan pada padat tebar yang tinggi. Bertitik tolak dari hasil penelitian Yusuf (2015) tersebut, maka penelitian ini melanjutkan menganalisis respon imun, infestasi parasit dan kelulushidupan ikan mas (Cyprinus carpio) yang dipapar dengan protein spora Myxobolus koi dan dipelihara pada media pembesaran ikan mas secara laboratorium.

\subsection{Rumusan Masalah}

Berdasarkan latar belakang yang sudah diuraikan di atas maka rumusan masalah dari penelitian ini adalah sebagai berikut :

1) Bagaimanakah gambaran darah (differensial Leukosit) ikan mas (Cyprinus carpio) yang dipapar dengan potein spora Myxobolus koi pada media air dari kolam pembesaran ikan sebagai bahan imunostimulan?

2) Berapa persen ikan mas (Cyprinus carpio) yang dipapar dengan potein spora Myxobolus koi sebagai bahan imunostimulan, terinfestasi parasit selama pemeliharaan pada media air dari kolam pembesaran?

3) Berapakah tingkat kelulushidupan atau survival rate (SR) ikan mas (Cyprinus carpio) yang dipapar dengan crude protein spora Myxobolus koi sebagai bahan imunostimulan pada media air dari kolam pembesaran?

\subsection{Tujuan Penelitian}

\subsubsection{Tujuan umum}

Tujuan umum dari penelitian ini adalah menganalisis gambaran darah (respon imun) dan kelulushidupan ikan mas (Cyprinus carpio) yang dipapar dengan protein spora Myxobolus koi pada media air dari kolam pembesaran ikan ?

\subsubsection{Tujuan khusus}

Tujuan khusus dari penelitian ini adalah sebagai berikut :

1) Menganalisis gambaran darah (differensial Leukosit) ikan mas (Cyprinus carpio) yang dipapar dengan crude protein spora Myxobolus koi sebagai bahan imunostimulan pada media air dari kolam pembesaran ikan.

2) Menganalisis infeksi Myxobolus koi pada ikan mas (Cyprinus carpio) yang dipapar dengan protein spora Myxobolus koi sebagai bahan imunostimulan pada media air dari kolam pembesaran.

3) Menganalisis tingkat kelulushidupan atau survival rate (SR) ikan mas 
(Cyprinus carpio) yang dipapar dengan protein spora Myxobolus koi pada media air dari kolam pembesaran.

\subsection{Manfaat Penelitian}

\subsubsection{Manfaat teoritis}

Hasil penelitian ini diharapkan dapat memberikan informasi ilmiah mengenai pengaruh pemaparan protein spora Myxobolus koi pada media pemeliharan pembesaran ikan mas (Cyprinus carpio)

\subsubsection{Manfaat Praktis}

Penelitian ini diharapkan dapat digunakan sebagai acuan dalam penggunaan protein spora Myxobolus koi ikan mas (Cyprinus carpio) yang dipelihara di tempat pembesaran ikan.

\section{TINJAUAN PUSTAKA}

\subsection{Ikan Mas (Cyprinus carpio)}

Ikan mas merupakan jenis ikan konsumsi air tawar, berbadan memanjang pipih kesamping dan lunak. Ikan mas sudah dipelihara sejak tahun 475 sebelum masehi di Cina. Di Indonesia ikan mas mulai dipelihara sekitar tahun 1920. Ikan mas yang terdapat di Indonesia merupakan ikan mas yang dibawa dari Cina, Eropa, Taiwan dan Jepang. Ikan mas Punten dan Majalaya merupakan hasil seleksi di Indonesia. Sampai saat ini sudah terdapat 10 ikan mas yang dapat diidentifikasi berdasarkan karakteristik morfologisnya (Pujiatmoko, 2008). Perbedaan sifat dan ciri dari ras disebabkan oleh adanya interaksi antara genotipe dan lingkungan kolam, musim dan cara pemeliharaan yang terlihat dari penampilan bentuk fisik, bentuk tubuh dan warnanya. Adapun ciri-ciri dari beberapa strain ikan mas adalah sebagai berikut :

1) Ikan mas punten mempunyai ciri sisik berwarna hijau gelap ; potongan badan paling pendek ; bagian punggung tinggi melebar; mata agak menonjol; gerakannya gesit; perbandingan antara panjang badan dan tinggi badan antara 2,3:1. Jenis ikan mas inilah yang digunakan dalam penelitian ini.

2) Ikan mas majalaya : sisik berwarna hijau keabu-abuan dengan tepi sisik lebih gelap ; punggung tinggi ; badannya relatif pendek ; gerakannya lamban, bila diberi makanan suka berenang di permukaan air ; perbandingan panjang badan dengan tinggi badan antara $3,2: 1$.

3) Ikan mas si nyonya : sisik berwarna kuning muda ; badan relatif panjang ; mata pada ikan muda tidak menonjol, sedangkan ikan dewasa bermata sipit ; gerakannya lamban, lebih suka berada di permukaan air ; perbandingan panjang badan dengan tinggi badan antara $3,6: 1$.

4) Ikan mas taiwan: sisik berwarna hijau kekuning-kuningan ; badan relative panjang ; penampang punggung membulat; mata agak menonjol ; gerakan lebih gesit dan aktif ; perbandingan panjang badan dengan tinggi badan antara 3,5:1.

5) Ikan mas koi : bentuk badan bulat panjang dan bersisisk penuh ; warna sisik bermacammacam seperti putih, kuning, merah menyala, atau kombinasi dari warna-warna tersebut.

\subsection{Myxobolus koi}

Myxobolus merupakan salah satu protozoa yang termasuk ke dalam famili Myxobolidae. Parasit ini memiliki spora berbentuk elipsoidal, ovoid atau membulat yang terlihat di dalam valvula (Lom \& Dykova, 1992). Selanjutnya dikatakan bahwa sistematika dari Myxobolus adalah sebagai berikut :

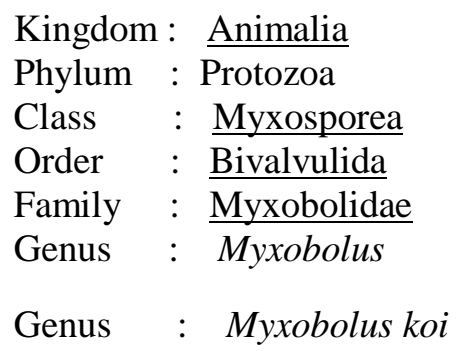

Myxobolus koi merupakan parasit yang menjadi agen penyebab penyakit whirling disease dan juga kerusakan beberapa organ pada ikan golongan cyprinidae. Myxobolus ini pertama kai ditemukan pada tahun 1986 di Timur Laut Pasifik (Lorz et al., 1989). Kejadian penyakit akibat infeksi parasit Myxosporea pada ikan dari berbagai kondisi geografis telah banyak diteliti dengan 
jumlah spesies sebanyak 1200 (Lom \& Dykova, 1992).

Myxobolus koi merupakan spesies yang paling banyak dari genus Myxosporea dan terdapat lebih dari 450 spesies yang telah teridentifikasi. Sebagian besar dari spesiesspesies tersebut memiliki sifat patogen yang baik pada ikan yang hidup bebas maupun ikan budidaya. Golongan Cyprinidae diketahui merupakan hospes untuk lebih dari 40 spesies Myxobolus, dimana Myxobolus cyprinii dan Myxobolus koi merupakan spesies patogen yang sering menyerang ikan golongan Cyprinidae, termasuk di dalamnya ikan mas (Kent, et al., 1996).

Myxobolus yang ditemukan pada ikan mas, merupakan parasit yang dikenal sebagai agen penyebab penyakit whirling disease ( $\mathrm{El}$ - Matbouli \& Hoffmann, 1998). Infeksi berat oleh parasit Myxobolus cerebralis dapat menyebabkan terjadinya deformitas tulang tengkorak ikan dan columna vertebralis dan juga kerusakan pada organ auditori yang menimbulkan gejaa whirling (Hoffman, 1992).

Umumya jumlah spora Myxobolus koi berjumlah 15.000 dalam satu nodul ukuran kecil, nodul berukuran milimeter dengan bentuk oval atau buat telur, ikan yang terserang Myxobolus koi akan terdapat nodul di bagian insang dan tubuh (Lom \& Dykova, 1992).

Bentuk spora Myxobolus dari masing - masing spesies yang ada mempunyai ukuran dan bentuk yangn berbeda-beda. Spora Myxobolus koi berbentuk seperti buah pear berukuran $\pm 14-15 \times 7-8 \mu \mathrm{m}$ sedangkan kista berdiameter $0.1-7 \mathrm{~mm}$ (Yuasa et al., 2003).

Myxobolus koi juga menginfeksi ikan mas pada ukuran kecil (stadium muda). Organ yang terinfeksi adalah insang, dimana parasit ini membentuk kista (cyste) pads lembarlembar insang ikan, sehingga akan mengganggu proses penyerapan zat asam . akan mengakibatkan ikan akan mengalami kekurangan zat asam karena sulit bernafas. Kematian yang diakibatkan oleh infeksi dari parasit ini cukup tinggi yaitu bisa mencapai 90\% (Ruliyandi, 2008). Selanjutnya dikatakan bahwa Myxosporeasis adalah merupakan penyakit parasiter pada ikan yang disebabkan oleh sporozoa, antara lain dari spesies Myxobolus koi. Umumnya organisme penyebab ini dikenali dengan morfologi sporanya, jumlah dan lokasi filamen polar. Spesies-spesies lain yang juga dapat menyebabkan penyakit ini adalah : Thelohanellus sp., Myxosoma sp., Henneguya sp. dan Maxidium sp

\subsection{Siklus hidup}

Lom and Dykova (2006) dan Darnas (1985), mengatakan bahwa cara penyebaran dari myxosporea sebenarnya belum dapat diketahui dengan pasti, namun ada keterangan yang menjelaskan bahwa beberapa Myxobolus memiliki siklus hidup secara langsung tanpa inang antara. Selanjutnya dikatakan bahwa siklus hidup diawali dari ikan yang terinfeksi Myxobolus koi ditemukan adanya nodul atau bisul yang terdapat pada insang ataupun pada permukaan tubuh. Setelah nodul matang, nodul tersebut akan pecah dan spora yang terdapat di dalam nodul menyebar di perairan yang kemudian termakan oleh ikan. Selanjutnya spora yang termakan oleh ikan akan masuk ke dalam saluran pencernaan. Kemudian kapsul polar melebur dan akan berbentuk seperti filamen polar dan akan bergelantungan di dinding usus. Selanjutnya akan menembus dinding usus ikan, kemudian masuk ke pembuluh darah dan menyebar ke seluruh organ ikan. Filamen polar tersebut akan mengalami perkembangan secara sporogony dan menjadi sporoblast dan membentuk nodul baru pada insang (Titis dkk, 2009).

Siklus hidup pada Gambar 2.2. menunjukkan adanya inang antara yaitu cacing Oligochaeta (e). Gambar tersebut dapat dijelaskan bahwa nodul yang berisi spora yang terdapat pada permukaan tubuh (epidermis) mengalami perkembangan jumlah spora $(\mathrm{a}, \mathrm{b}$ dan c) dan kematangan nodul. Setelah matang nodul akan pecah dan mencemari perairan (d). Selanjutnya spora akan termakan oleh cacing Oligochaeta dan di dalam tubuh cacing ini spora mengalami perkembangan menjadi spora triactinomyxon (aktinospora) dan akan termakan oleh ikan kemudian membentuk nodul kembali (El-Matbouli et al., 1998).

Menurut Darnas (1985), daur hidup 
Jurnal Biosains Pascasarjana Vol. 19 (2017) pp

(C) (2017) Sekolah Pascasarjana Universitas Airlangga,

myxobolus diawali dengan spora termakan 
oleh ikan dan masuk ke dalam saluran pencernaan ikan. Cairan dalam saluran pencernaan ikan dapat membantu spora melepaskan filamen polar untuk menempel pada sel setelah bagian internal spora (sporoplasma) berubah bentuk menjadi amoeboid dan melakukan penetrasi ke dalam sel usus atau dalam sel darah untuk menuju organ target. Pada kondisi ini parasit disebut thropozoit kemudian membelah (shizogony) dan bercampur (sporogony) sehingga menghasilkan massa spora.

Lebih lanjut Anshary (2008)
menyatakan bahwa ikan terinfestasi
Myxobolus setelah memakan spora. Di dalam
usus terjadi stimulasi polar kapsul menjadi
terbuka dan mengeluarkan polar filamen yang
melekat pada epitelium usus, selanjutnya valve
menjadi terbuka dan amoebula keluar.
Amoebula mengikuti aliran darah dan darah
membawa ke organ target. Amoebula yang
telah mencapai organ target akan tumbuh
menjadi zigot dan inti sel mengalami
pembelahan beberapa kali untuk membentuk
sporogonik plasmodium.

\subsection{Myxobolusis pada Ikan}

Myxobolusis merupakan penyakit parasiter pada ikan yang disebabkan oleh Myxobolus. Parasit yang menyerang insang ini diklasifikasikan ke dalam kelompok khusus dari myxosporea. Beberapa spesies parasit dapat menginfeksi satu ikan, membentuk tiga koloni yang berbeda di jaringan insang (Eszterbauer et al., 2001). Myxobolus merupakan salah satu genus dari Myxosporea, yang bersifat parasit dan menyerang kulit dan insang ikan air tawar maupun ikan air laut. Beberapa spesies myxosporea telah dilaporkan namun sejauh ini hanya beberapa yang menimbulkan infeksi serius. Gejala infeksi yang biasa terlihat seperti adanya cyste di antara jaringan insang dan integument yang terdiri dari perkembangan stadia parasit, termasuk karakteristik dari spora (Robert, 1989).

Myxobolusis umumnya menginfeksi jaringan ikat tapis insang, tulang kartilago, otot atau daging dan beberapa organ dalam ikan terutama pada benih. Pada insang akan terlihat bisul atau nodul putih seperti tumor berbentuk bulat lonjong menyerupai butiran padi. Pada infeksi berat, tutup insang (operculum) tidak 
Jurnal Biosains Pascasarjana Vol. 19 (2017) pp

(C) (2017) Sekolah Pascasarjana Universitas Airlangga,

dapat menutup sempurna (Kementrian Perikanan dan Kelautan, 2010). Secara umum, infeksi berat pada insang akan menyebabkan penurunan berat badan, ikan berenang di dekat pematang kolam, warna kulit pucat dan ikan kesulitan untuk bernafas yang dapat berakibat pada kematian (Sugianti dkk, 2005).

Myxobolus yang menyerang ikan air tawar pernah dilaporkan di Indonesia menyebabkan masalah serius dalam budidaya ikan koi (Cyprinus carpio), dengan tingkat mortalitas 60 - 90\% pada benih ikan koi. Myxobolus yang menghasilkan nodul pada filamen insang ikan koi telah diidentifikasi sebagai jenis Myxobolus koi (Kudo, 1977). Parasit ini telah masuk ke Indonesia melalui ikan koi impor dan menyebabkan kerugian yang cukup besar pada budidaya ikan koi (Rukyani, 1990). Menurut Badan Karantina Ikan, Pengendalian Mutu dan Keamanan Hasil Perikanan (2011), myxobolusis pada ikan koi dikategorikan pada HPIK (hama dan penyakit ikan karantina) golongan I karena belum dapat disucihamakan dan/atau dihilangkan dari media pembawanya karena teknologi perlakuaan belum dikuasai.

Titis (2009) melaporkan bahwa serangan Myxobolus menyebabkan kematian sekitar 50\% dari ikan yang terinfeksi. Menurut Wijanarko (2011), di Desa Tlogo Kemacatan Kanigoro Kabupaten Blitar sering ditemukan serangan parasit Myxobolus pada benih ikan Mas. Warga setempat sering menamakan dengan "tumor ikan". Devi (2011) juga melaporkan jumlah nodul pada ikan mas yang terserang Myxobolusis di Kabupaten Blitar Jawa Timur, dari 200 ikan yang positif terinfeksi Myxobolus 19\% merupakan infeksi berat, $55,5 \%$ infeksi sedang dan $25,5 \%$ merupakan infeksi ringan dari total sampel. Lebih lanjut, Firmansyah (2012) melaporkan prevalensi dan jumlah nodul ikan koi yang terserang myxobolusis dari tiga Desa di Kabupaten Blitar yakni Desa Penataran, Desa Nglegok dan Desa Kemloko, diperoleh prevalensi tertinggi di Desa Kemloko yakni sebanyak $19,46 \%$ ikan yang terinfeksi Myxobolus dari 550 sampel ikan dimana $27,10 \%$ merupakan infeksi sedang dan $11,21 \%$ merupakan infeksi berat dari total ikan yang terserang

myxobolusis. 
Diagnosa myxobolusis dapat dilakukan dengan melakukan pengamatan secara visual terhadap tingkah laku dan gejala klinis pada ikan. Pengamatan lebih lanjut dapat dilakukan secara mikroskopis untuk melihat morfologi Myxobolus melalui pembuatan preparat ulas dari organ target (Stoskopf, 1993).

\subsection{Protein Spora Myxobolus}

Protein dari pathogen (parasit, bakteri, virus dan jamur) dapat digunakan sebagai bahan yang dapat meningkatkan proliferasi sel pada ikan. Antigen merupakan suatu molekul yang mampu berikatan dengan antibody spesifik. Sedang antigenik adalah sifat suatu molekul atau zat yang memungkinkan untuk bereaksi dengan produk-produk dari respons imun spesifik, seperti antibodi (Tizard, 1988). Selanjutnya dikatakan bahwa terdapat dua ciri pokok antigenitas yaitu limitasi fisikokimiawi dan keasingan. Limitasi fisikokimiawi berarti bahwa agar dapat bersifat antigenik molekul harus besar, kaku dan kimiawi kompleks. Molekul kecil juga dapat berlaku sebagai antigen, akan tetapi molekul besar jauh lebih baik. Protein merupakan antigen yang baik karena merupakan makromolekul dan mempunyai struktur kimia yang kompleks. Keasingan artinya adalah sifat dasar bahan asing yang dapat dikenal sebagai bukan unsur tubuh yang normal. Protein dapat merupakan antigen yang baik bila mempunyai berat molekul lebih besar dari 1.000 Dalton dan mempunyai kerumitan struktur. Baratawidjaja (2004) mengatakan bahwa antigen yang juga disebut dengan imunogen adalah bahan yang dapat merangsang respons imun atau bahan yang dapat bereaksi dengan antibodi yang sudah ada tanpa memperhatikan kemampuannya untuk merangsang produksi antibodi.

Protein spasmin merupakan protein membran yang terdapat pada spasmonema pada tangkai (contractile stalk) pada berbagai spesies dari familia Vorticellidae (Amos, et al., 1975; Routledge, 1978; Moriyama, et al., 1999; Mcutcheon, et al., 2002; Pylawka dan Buhse, 2003 dan Itabashi, et al., 2003).

Amos, et al.,
menganalisis protein kontraktil dari Zoothamnium arbuscula dan membandingkan dengan protein lain pada 
Jurnal Biosains Pascasarjana Vol. 19 (2017) pp

(C) (2017) Sekolah Pascasarjana Universitas Airlangga,

organ lain yang berkontraksi. Deteksi protein ini dilakukan dengan Polyacrylamide Gel, hasil dari penelitian ini menunjukkan bahwa hampir $60 \%$ protein di dalam Sodium Dodecyl Sulphate Gels tersebar pada pita (band) dengan berat molekul mendekati 20,000 kDa. Protein ini terdiri dari 2 protein yang sama besar yang disebut dengan protein spasmin 1 dan 2 . Komposisi asam amino dari ke dua fraksi spasmin tersebut yang dideterminasi dengan metode Flourimetrik menunjukkan kaya dengan glysin dan serin tetapi tidak mengandung cystein dan methionin.

Itabashi, et al. (2003) telah melakukan karakterisasi molekuler protein spasmin Zoothamnium arbuscula, hasil yang didapat menunjukkan bahwa satu gen spasmin tidak mempunyai intron dan panjang genom $531 \mathrm{bp}$ dan diprediksi akan menghasilkan 177 asam amino dengan berat molekul mendekati 19.659 Da $(19,659 \mathrm{kDa})$. Sekuen asam mempunyai dua ikatan kalsium. Karakterisasi protein spasmin zoothamnium banyak dilakukan dengan metode SDS-PAGE dengan kadar gel $10 \%$ dapat digunakan untuk identifikasi berat molekul protein, hasil identifikasi berupa pita (band) dan penentuan berat molekulnya dilakukan dengan cara melihat kesetaraan dengan marker.

Itabashi, et al. (2004) menyatakan bahwa protein spasmin pada spasmonema Zoothamnium arbuscula sudah dapat dibuat antibodi poliklonal pada sel hela. Analisis hasil immunoblotting menunjukkan bahwa lokasi protein antigen pada berat molekul 68/71 kDa, 55 kDa dan 70 kDa. Brunk (1999) merekomendasi bahwa protein membran Tetrahymena sp. yang merupakan satu familia dengan Ichthyophthyrius multifiliis mempunyai kemungkinan besar dikembangkan sebagai bahan vaksin sub unit terhadap penyakit bintik putih (white spot) pada ikan. Preer (1986) menemukan protein membran antigenik pada Paramecium dengan SDS-PAGE dan Western Blotting, dengan berat molekul $61 \mathrm{kDa}, 63 \mathrm{kDa}$ dan $65 \mathrm{kDa}$.

Lin, et al. (1996) menemukan protein membran antigenik dari theront Ichthyophthyrius multifiliis serotype $\mathrm{G} 1$ berat molekul $48 \mathrm{kDa}$ dan $60 \mathrm{kDa}$, dan serotype G3 dengan berat molekul $55 \mathrm{kDa}$, dengan metode standart. Sedangkan Maki dan Dickerson 
(2003) sudah berhasil mengekstrasi protein membran theront Ichthyophthyrius multifiliis serotype G5 dan mengidentifikasi SDS-PAGE $12 \%$ serta Western Blotting yang dilajutkan pemurnian dengan Kromatografi Imunoafinitas. Hasil penelitian ini menunjukkan bahwa telah ditemukan protein membran imunogenik dengan berat molekul $55 \mathrm{kDa}$ dan $35 \mathrm{kDa}$.

Yusuf (2015) telah berhasil mengisolasi whole protein spora Myxobolus koi menggunakan SDS-PAGE, yang ditemukan adanya protein digambarkan dalam bentuk pita-pita pada gel SDS-PAGE dan ditemukan 6 pita (band) protein yaitu dengan berat molekul $68.1 \mathrm{kDa}, 38.5 \mathrm{kDa}, 25.6 \mathrm{kDa}$, $23 \mathrm{kDa}, 21.7 \mathrm{kDa}$ dan $18.9 \mathrm{kDa}$. Hasil analisis SDS-PAGE dapat dilihat pada Gambar 2.3. Selanjutnya dikatakan bahwa protein tersebut sudah diuji coba secara laboratoris dapat meningkatkan respon imun dan kelulushidupan ikan koi dari 19\% hingga $78 \%$ dan dapat dikembangkan sebagai bahan vaksin sub unit.

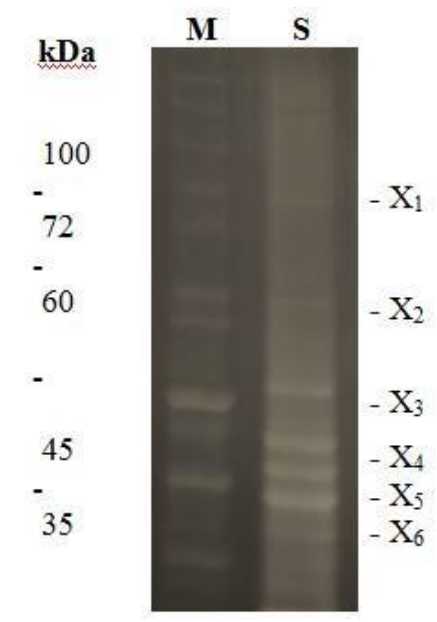

Gambar 2.4. Hasil karakterisasi whole protein spora Myxobolus koi dengan SDS-PAGE menggunakan pewarnaan perak nitrat (Yusuf, 2015).

Keterangan : Lajur (M): Marker dan lajur (S): whole protein sampel

\subsection{Sistem Pertahanan Tubuh pada Ikan}

Respons imunitas pada hewan merupakan upaya perlindungan diri terhadap infeksi maupun preservasi fisiologik - homeostasi. Respons imunitas hewan akuatik terdiri dari respons non spesifik dan spesifik. Respons imunitas pada ikan dibentuk oleh jaringan limfoid. Jaringan limfoid ikan menyatu dengan jaringan mieloid yang disebut sebagai jaringan limfomieloid. Pada ikan teleost jaringan limfomieloidnya adalah limfa, timus dan ginjal depan (Van Muiswinkel, 2008).

Berbeda dengan udang, pada ikan terdapat populasi sel B dan sel T. Sel ini sangat berperan dalam respons imunitas baik seluler maupun humoral. Respons dan faktor humoral antara lain antibodi, transferin, interferon, protein C-reaktif; respons dan faktor seluler seperti sel makrofag, sel killer, neutrofil dan hipersensitivitas. Selain itu barier mekanik dan kimiawi permukaan seperti kulit, sisik dan mukus pada permukaan tubuh dan insang juga merupakan alat pertahanan tubuh ikan yang bersifat non spesifik (Randelli et al., 2008).

Respons humoral merupakan respons yang bersifat spesifik dilakukan oleh suatu substansi yang dikenal sebagai antibodi atau imunoglobulin, sedangkan respons seluler ikan bersifat non spesifik dilakukan oleh "cell mediated imunity" (Alejo and Tafalla, 2011). Komunikator dan amplikator dalam fungsi dan mekanisme pertahanan

humoral dan seluler ikan dilakukan oleh limfokin, interleukin, interferon dan sitokin (Sommerset et al., 2005).

\subsection{Gambaran darah ikan}

Kurniawan (2010) menyebutkan bahwa darah merupakan salah satu komponen transport yang vital keberadaannya yaitu sebagai pengangkut bahan kimia seperti hormon (hasil kelenjar endokrin) ke sel atau organ, bahan buangan hasil metabolisme tubuh, dan pengangkut oksigen dan karbondioksida. Volume darah ikan yang beredar dalam sistem sirkulasi sekitar 1,5-3\% dari berat tubuhnya. Nilai ini jauh dibawah volume darah mamalia yaitu mencapai $6 \%$ dari tubuhnya, namun pada spesies ikan tertentu mempunyai volume darah sekitar 5\% dari berat tubuhnya (Triastuti dkk., 2010). Darah terdiri atas komponen cairan dan komponen seluler. Komponen cairan disebut plasma darah, dan komponen seluler meliputi erythrocytes (sel darah merah), leucocytes (sel darah putih) dan thrombocytes (keping darah) (Suprapto, 2007). Komponen darah ikan seperti 
trombosit dan plasma darah memiliki peran penting sebagai pertahanan pertama terhadap serangan penyakit yang masuk ke dalam tubuh ikan. Gambaran darah dapat digunakan untuk mengetahui kondisi kesehatan ikan. Penyimpangan fisiologis ikan akan menyebabkan komponen-komponen darah juga mengalami perubahan (Kurniawan, 2010).

\subsubsection{Eritrosit (sel darah merah)}

Eritrosit berwarna merah kekuningan dengan jumlah berkisar antara 20 ribu sampai 3 juta tiap conya. Jumlah sel ini tergantung aktivitas ikan dan suhu tubuhnya. Eritrosit memiliki fungsi untuk mengangkut hemoglobin yang berperan membawa oksigen dari insang ke jaringan, eritrosit mengandung asam karbonat dalam jumlah besar yang berfungsi mengkatalis reaksi antara $\mathrm{CO}_{2}$ dan air, dengan demikian darah darah dapat bereaksi dengan karbondioksida dan mentranspornya dari jaringan ke insang (Sulmartiwi dan Suprapto, 2011).

Diameter eritrosit ikan antara $7-36 \mu$. Eritrosit yang sudah matang berbentuk oval, sedangkan pada sel yang belum matang berbentuk bulat (Triastuti dkk., 2010). Inti sel eritrosit terletak sentral dengan sitoplasma dan akan terlihat jernih kebiruan dengan pewarnaan giemsa (Kurniawan, 2010). Irianto (2005) menyebutkan bahwa pada ikan teleostei, jumlah normal eritrosit adalah $1,05 \times 10^{6}-$ $3,0 \times 10^{6} \mathrm{sel} / \mathrm{mm}^{3}$, sedangkan dalam persentase jumlah terendah eritrosit $96,5 \%$ dan tertinggi 98\%. Angka et al., (1985) dalam Dopongtunung (2008) menyatakan bahwa ukuran eritrosit ikan lele berkisar antara $10 \mathrm{x} 11 \mu \mathrm{m}-12 \mathrm{x} 13 \mu \mathrm{m}$, dengan diameter inti berkisar antara 4-5 $\mu \mathrm{m}$. Jumlah eritrosit ikan lele adalah $3,18 \times 10^{6} \mathrm{sel} / \mathrm{ml}$.

\subsubsection{Leukosit (sel darah putih)}

Leukosit memiliki peranan utama dalam sistem pertahanan tubuh. Leukosit juga berperan dalam detoksifikasi protein sebelum dapat menyebabkan kerusakan dalam tubuh (Sulmartiwi dan Suprapto, 2011). Fujaya (2004) menyatakan bahwa ikan memiliki leukosit (sel darah putih) yang lebih banyak dari manusia yaitu berkisar antara 137.000$198.000 \mathrm{sel} / \mathrm{mm}^{3}$. Roberts (1989) menyatakan bahwa pada kondisi ikan terinfeksi penyakit menyebabkan jumlah leukosit yang ada di dalam darah akan lebih banyak dari kondisi normal. Hal ini disebabkan sel leukosit banyak terdapat di jaringan haemopoeitik ginjal dan akan dilepaskan dalam darah sebagai respon non spesifik untuk mempertahankan tubuh dari serangan penyakit.

Sulmartiwi dan Suprapto (2011) mengatakan bahwa leukosit terbagi menjadi dua macam berdasarkan adanya granul dalam sitoplasma yakni, tipe granulosit (eosinofil, basofil dan neurofil) dan agranulosit (monosit dan limfosit). Eosinofil, neutrofil, dan monosit merupakan sel darah putih yang berfungsi sebagai fagositosis. Eosinofil merupakan fagosit lemah, sedangkan neutrofil dan monosit merupakan fagosit kuat. Limfosit tidak bersifat fagositik tetapi memegang peranan dalam pembentukan antibodi. Kekurangan limfosit menyebabkan menurunnya konsentrasi antibodi dan meningkatnya serangan penyakit. Persentase jumlah monosit berkisar antara 3-5\%, limfosit berkisar antara 76-97,5\%, granulosit berkisar antara 2-10\%, eosinofil granulosit berkisar antara $0-1 \%$ dan basofil granulosit berkisar antara $0-0,5 \%$ (Svobodova and vykusova, 2008).

\section{METODE PENELITIAN}

\subsection{Waktu dan Tempat Penelitian}

Penelitian ini telah dilaksanakan pada bulan April 2017. Semua tahapan penelitian mulai aplikasi pemaparan protein spora Myxobolus koi, pemeriksaan gambaran darah, dan kelulushidupan dilakukan di Laboratorium Basah Fakultas Perikanan dan Kelautan Universitas Airlangga Surabaya. Pengamatan differensial leukosit ikan dan infestasi parasit dilakukan di Laboratorium Kering Fakultas Perikanan dan Kelautan Universitas Airlangga Surabaya.

\subsection{Rancangan Penelitian :}

Penelitian ini merupakan penelitian eksperimen laboratorik, untuk menganalisis respon imun (Gambaran Darah), infeksi parasit dan kelulushidupan ikan mas yang dipapar dengan protein spora Myxobolus koi. Penelitian eksperimental adalah penelitian yang dilakukan dengan mengadakan manipulasi terhadap obyek penelitian dan 
Jurnal Biosains Pascasarjana Vol. 19 (2017) pp

(C) (2017) Sekolah Pascasarjana Universitas Airlangga,

adanya kontrol. Penelitian eksperimental

bertujuan untuk menyelidiki ada tidaknya 
hubungan sebab akibat serta berapa besar hubungan sebab akibat tersebut dengan cara memberikan perlakuan-perlakuan tertentu dan menyediakan kontrol untuk perbandingan (Steel and Torrie, 1992)

Ikan mas diuji dengan menggunakan 3 akuarium dengan kapasitas 20 lt air. Padat tebar ikan adalah 20 ekor/akuarium dengan ukuran ikan 7-10 cm. Pemaparan protein spora Myxobolus koi dilakukan secara oral yaitu disuntikkan langsung melalui mulut ikan. Ikan yang digunakan untuk perlakuan adalah ikan sehat yang telah direndam dahulu dalam Methylene blue $3-5 \mathrm{~g} / \mathrm{m}^{3}$ air selama 5 menit untuk membersihkan organisme yang menempel pada tubuh ikan.Adapun perlakuan pemaparan protein spora selama pemeliharaan adalah sebagai berikut :

$\mathrm{K} 1$ = Ikan mas sebanyak 30 ekor dipapar dengan larutan PBS, tanpa dipapar protein spora Myxobolus koi dan dipelihara pada media air bukan air kolam pembesaran (air PDAM).

$\mathrm{K} 2$ = Ikan mas sebanyak 30 ekor dipapar protein spora Myxobolus koi dengan dosis $2 \mu \mathrm{g}$ protein/gram dan dipelihara pada media air dari kolam pembesaran

$\mathrm{K} 3$ = Ikan mas sebanyak 30 ekor dipapar dengan larutan PBS, tanpa dipapar protein spora Myxobolus koi dan dipelihara pada media air dari kolam pembesaran

\subsection{Variabel Penelitian}

Variabel dalam penelitian ini digolongkan menjadi variabel bebas, variabel tergantung dan variabel kendali. Variabel bebas yaitu dosis protein Myxobolus koi. Variabel tergantung yaitu respon imun (differensial leukosit), infestasi parasit dan kelulushidupan (survival rate) ikan mas. Variabel kendali yaitu umur dan ukuran ikan mas, ukuran akuarium dan kualitas air dan pakan.

\subsection{Definisi Operasional}

1) Myxobolusis adalah salah satu jenis penyakit pada ikan koi yang disebabkan oleh Myxobolus koi.

2) Ikan mas sehat adalah ikan mas yang memiliki ciri-ciri tubuh bersih dari parasit, warna cerah, pergerakan lincah, organ tubuh lengkap dan tidak rusak.

3) Ikan mas terinfeksi Myxobolus koi adalah ikan mas yang ditemukan nodul berisi spora dan sulit bernafas.

4) Infestasi parasit adalah banyaknya parasit (jumlah) yang menyerang ikan mas.

5) Tingkat kelulushidupan (SR) merupakan persentase jumlah ikan koi yang hidup selama pemeliharaan terhadap jumlah keseluruhan ikan yang dipelihara.

\subsection{Materi Penelitian}

4.5.1. Peralatan Penelitian

Peralatan yang digunakan dalam penelitian ini adalah : nampan bedah, mikroskop cahaya, pinset, cawan petri, pipet, tabung reaksi, object glass, cover glass, Beaker glass, 20 buah akuarium dengan kapasitas 15 liter, selang dan batu aerasi. Peralatan untuk menganalisis leukosit (respon imun) adalah : Staining Jare, Spuit $1 \mathrm{ml}$, Mikroskoskop perbesaran 1000X dan Haemositometer. Peralatan untuk mengukur parameter kualitas air meliputi : Thermometer untuk mengukur suhu air, Refraktometer untuk mengukur salinitas, $\mathrm{pH}$ meter untuk mengukur $\mathrm{pH}$, DO-meter untuk mengukur oksigen terlarut dan tes kit untuk mengukur $\mathrm{NH}_{3}$ dan alkalinitas.

\subsubsection{Bahan Penelitian}

Ikan mas yang digunakan dalam penelitian adalah ikan mas sehat (tidak terinfeksi Myxobolus) dengan ukuran $10 \mathrm{Cm}$. Jumlah sampel ikan mas sehat sebanya 80 ekor. Protein spora Myxobolus koi sebagai bahan pengembangan imunostimulan. Protein ini merupakan protein hasil isolasi dan karakterisasi dengan SDS-PAGE dan sudah diuji tantang secara laboratories oleh Yusuf (2015). Bahan yang digunakan untuk pemeriksaan differential leukosit adalah anti koagulan (EDTA), Metanol, Giemsa 20\% dan minyak emersi. Air yang digunakan untuk pemeliharaan ikan mas yang dipapar protein spora adalah air kolam pembesaran ikan mas di kecamatan Dlanggu Mojokerto.

\subsection{Metode Penelitian}

Metode penelitian yang digunakan

dalam penelitian ini adalah eksperimental 
laboratorik untuk menganalisis respons imun ikan mas yang dipapar dengan protein spora Myxobolus koi. Penelitian eksperimental adalah penelitian yang dilakukan dengan mengadakan manipulasi terhadap obyek penelitian dan adanya kontrol. Penelitian eksperimental bertujuan untuk menyelidiki ada tidaknya hubungan sebab akibat serta berapa besar hubungan sebab akibat tersebut dengan cara memberikan perlakuan-perlakuan tertentu dan menyediakan kontrol untuk perbandingan (Steel and Torrie, 1992).

\subsection{Pelaksanaan Penelitian}

\subsubsection{Penyediaan Protein Spora Myxobolus koi \\ Bahan pengembangan dari protein} spora Myxobolus koi menggunakan bahan yang sudah dilahsilkan Yusuf (2015) dan Woro (2015). Bahan spora ini sudah diuji tantang secara laboratoris. Hasil penelitian secara laboratoris menunjukkan hasil bahwa spora Myxobolus koi dapat dikembangkan sebagai vaksin sub unit.

\subsubsection{Pemeriksaan Infeksi Parasit}

Pengamatan parasit pada insang dilakukan secara natif dengan metode Jhonson (1986), yaitu dengan melakukan pengerokan pada seluruh permukaan tubuh udang. Hasil kerokan ditaruh di atas gelas obyek, diberi air dan diperika dengan mikroskop dengan pembesaran 100X. Infestasi parasit dihitung dengan persentasi udang yang positif terhadap jumlah udang yang diperiksa. Kemudian pemeriksaan parasit saluran pencernaan dilakukan dengan cara mengeluarkan seluruh isi saluran pencernaan, ditampung dalam petridisk dan diperiksa secara natif dengan pembesaran 100X.

\subsubsection{Analisis Gambaran Darah (Differensial leukosit)}

Pengamatan gambaran darah ikan mas dilakukan untuk menganalisis respons imun ikan mas yang dipapar dengan protein spora M. koi. Parameter gambaran darah yang diamati adalah hitung jenis (differensial) leukosit. Leukosit memiliki jumlah yang lebih sedikit dibandingkan dengan sel darah merah, yaitu berkisar antara 20.000/mm3 sampai $150.000 / \mathrm{mm} 3$ (Levine, 1994). Bentuk sel darah putih menurut Ariaty (1991) adalah berbentuk lonjong sampai bulat. Guyton and Hall (1999) melaporkan bahwa leukosit terdiri dari agranulosit (limfosit dan monosit) dan granulosit (heterofil, eosinofil dan basofil).

Jenis dan jumlah leukosit dihitung dengan metode Daisley (1973). Darah diambil dari vena caudal dengan menggunakan spuit 1 $\mathrm{ml}$ sebanyak $\pm 1 \mathrm{ml}$. Pada saat pengambilan darah, ikan diletakkan dengan kepala di sebelah kiri. Jarum suntik (syringe) yang sebelumnya sudah diberi dengan EDTA (sebagai antikoagulan). Darah dibuat preparat ulas dengan cara menempatkan setetes darah segar pada gelas objek pertama, gelas objek kedua diletakan dengan suduk $45^{\circ}$ terhadap gelas objek pertama, kemudian ditarik sampai menyentuh darah, darah dibiarkan menyebar sepanjang tepi gelas objek kedua, lalu gelas objek kedua didorong sepanjang permukaan gelas objek pertama sehingga membentuk lapisan darah tipis dan merata (Maswan, 2009). Preparat dikeringkan di suhu ruang kemudian difiksasi dengan metanol absolute selama 3 menit dan dikeringkan di suhu ruang kembali sebelum diwarnai dengan pewarna Giemsa 10\% selama 15 menit, lalu preparat dicuci kembali dengan akuades untuk mengurangi kelebihan warna dan dikeringkan di suhu ruang. Preparat diamati di bawah mikroskop dengan perbesaran 1000x dan dihitung setiap jenis leukosit hingga jumlah 100 sel (Tambur et al., 2006).

\subsubsection{Penentuan kelulushidupan (SR)}

Penentuan tingkat kelulushidupan (survival rate) dilakukan sebagai parameter penunjang untuk menganalisis respons imun ikan mas pada masing - masing perlakuan. Tingkat kelulushidupan dinyatakan berupa persentase jumlah ikan koi yang hidup sampai dengan hari ke-14 pasca perlakuan percobaan terhadap jumlah keseluruhan ikan yang dipelihara. Kelulushidupan ikan dihitung dengan menggunakan rumus:

$$
\mathrm{SR}=\frac{\mathrm{Nt}}{\mathrm{No}} \times 100 \%
$$

Keterangan :

$\mathrm{SR}=$ Kelulushidupan ikan 
$\mathrm{Nt}=$ Jumlah ikan yang hidup pada akhir pengamatan (ekor)

No = Jumlah ikan yang hidup pada awal uji tantang (ekor)

\subsection{Pengumpulan dan Analisis Data}

Data yang terkumpul dianalisis secara diskrptif yaitu dengan tabel dan gambar serta dilakukan penjelasan terhadap data tersebut (Steel and Torrie, 1992).

\section{HASIL DAN PEMBAHASAN}

\subsection{Hasil Penelitian}

\subsubsection{Analisis Gambaran Darah Ikan Mas}

Hasil analisis gambaran darah (Differensial leukosit) ikan mas yang dipapar dengan protein spora Myxobolus koi dapat dilihat pada Tabel 5.1.

Tabel 5.1. Hasil Analisis Differensial Leukosit pada ikan koi.

\begin{tabular}{|c|c|c|c|c|c|}
\hline \multirow{2}{*}{ PERLAKUAN } & \multicolumn{5}{|c|}{ JENIS LEUKOSIT (\%) } \\
\cline { 2 - 6 } & LIMFOSIT & MONOSIT & HETEROFIL & EOSINOFIL & BASOFIL \\
\hline K1 & 57,8 & 12,8 & 3,4 & 6,8 & 0,9 \\
\hline K2 & 77,6 & 16,3 & 14,4 & 7,6 & 0,4 \\
\hline K3 & 61,5 & 11,6 & 6,7 & 9,2 & 0,2 \\
\hline N0RMAL & $76-97,5 \%$ & $\mathbf{3 - 5 \%}$ & $2-10 \%$ & $0-1 \%$ & $0-0,5 \%$ \\
\hline
\end{tabular}

Tabel 5.1 menunjukkan bahwa persentase dari masing-masing komponen leukosit berada dalam kondisi normal dan beberapa juga berada pada kondisi di bawah normal. Dilihat dari gambaran limfosit menunjukkan limfosit tertinggi terjadi pada ikan mas yang dipapar dengan protein spora Myxobolus koi dan dipelihara pada media air dari kolam pemeliharaan ikan dari Mojokerto (Perlakuan K2) yaitu sebesar 77,6\%, kemudian diikuti pada ikan mas yang tidak dipapar dan dipelihara pada media air dari kolam pemeliharaan yaitu sebesar $61,5 \%$ dan terendah pada perlakuan K3 yaitu ikan mas yang tidak dipapar protein dan dipelihara pada media air yang steril dari air PDAM.

Dilihat dari persentase komponen leukosit yang lain yaitu monosit, heterofi, eosinofil dan basofil, hanya monosit yang berada dalam persentase di atas normal pada semua perlakuan yaitu $\mathrm{K} 1, \mathrm{~K} 2$ dan $\mathrm{K} 3$, berturut-turut yaitu 12,8 ; 16,3 dan 11,6\%. Untuk ikan mas pada perlakuan K2 semuanya menunjukkan pada kondisi di atas normal kecuali basofil dan eosinofil semua masih di atas normal, yaitu 0,9 untuk basofil dan eosinofil semuanya di atas normal, berturut- turut pada perlakuan $\mathrm{K} 1, \mathrm{~K} 2$ dan $\mathrm{K} 3$, yaitu $6,8,7.6$ dan $9,8 \%$.

\subsubsection{Hasil Pemeriksaan Infestasi Parasit}

Periksaan infestasi parasit ini hanya ditujukan untuk pemeriksaan terhadap Myxobolus koi. Hasil pemeriksaan dapat dilihat pada Tabel 5.2. yang menunjukkan bahwa semua ikan mas, baik yang dipapar maupun tidak dipapar protein spora Myxobolus koi terinfestasi Myxobolus koi.

Tabel 5.2. menunjukkan bahwa persentasi kan mas yang terinfestasi parasit tertinggi sebesar 53,33\% terjadi pada ikan yang tidak dipapar protein spora Myxobolus koi dan dipelihara pada media air yang diambil dari kolam mas yang tidak dipapar protein yang dipelihara pada media air yang sudah disterilkan yaitu $30,00 \%$, sedangkan yang terrendah $(16,66 \%)$ terjadi pada ikan yang dipapar dengan protein dan dipelihara dengan air media yang diambil dari kolam pemeliharaan ikan di Desa Delanggu, Mojokerto.

Tabel 5.2. Hasil Pemeriksaan Infestasi Myxobolus koi Pada Ikan Mas Setelah 30 Hari Pemeliharaan

\begin{tabular}{|c|c|c|c|}
\hline \multirow{2}{*}{ Perlakuan } & \multirow{2}{*}{$\begin{array}{c}\text { Jumlah Ikan } \\
\text { Yang } \\
\text { Diperiksa } \\
\text { (Ekor) }\end{array}$} & \multicolumn{2}{|c|}{$\begin{array}{c}\text { Infestasi Myxobolus koi pada Ikan } \\
\text { Mas(Ekor / \%) }\end{array}$} \\
\hline & & Positif & Negatif \\
\hline K1 & 30 & $9(30,00)$ & $21(70,00)$ \\
\hline K2 & 30 & $5(16,66)$ & $25(83,33)$ \\
\hline K3 & 30 & $16(53,33)$ & $14(46,66)$ \\
\hline
\end{tabular}

\subsubsection{Penentuan Tingkat Kelulushidupan (SR) Ikan Mas}

Kelulushidupan udang vaname dihitung pada saat panen yaitu pada hari ke 90 . Hasil penghitungan tingkat kelulushidupan

ikan mas menunjukkan bahwa tingkat kelulushidupan ikan mas yang dipapar dengan protein protein spora Myxobolus koi dan dipelihara pada media air dari kolam pemeliharaan ikan nila di Mojokerto, mencapai $90 \%$, sedangkan yang tidak dipapar protein sebesar $73 \%$ yang dipelihara pada air PDAM dan 53,33\% ikan mas yang dipelihara pada media air dari kolam pemeliharan ikan nila di Mojokerto (Tabel 5.3). 
Tabel 5.3. Hasil Penentuan Tingkat Kelulushidupan Ikan Mas

Tabel 5.3. menunjukan bahwa kelulushidupan ikan mas yang tertinggi terjadi pada ikan mas yag dipapar dengan protein spora Myxobolus koi yaitu sebesar 90\%. Kemudian diikuti pada ikan mas yang tidak dipapar protein spora yaitu 73,33\%. Persentase kelulushidupan ikan mas terrendah ditemukan pada ikan mas tidak dipapar protein spora dan dipelihara pada media air dari kolam perairan

\begin{tabular}{|c|c|c|c|}
\hline Perlakuan & $\begin{array}{c}\text { Jumlah Ikan } \\
\text { Mas yang } \\
\text { dipelihara }\end{array}$ & $\begin{array}{c}\text { Jumlah Ikan Mas yang } \\
\text { Hidup setelah 30 hari } \\
\text { Pemeliharaan }\end{array}$ & $\begin{array}{c}\text { Tingkat } \\
\text { Kelulushidupan } \\
(\%)\end{array}$ \\
\hline K1 & 30 & 22 & 73,33 \\
\hline K2 & 30 & 27 & 90,00 \\
\hline K3 & 30 & 16 & 53,33 \\
\hline
\end{tabular}

budidauya, yaitu sebesar 53,33\%\$.

\subsubsection{Kualitas air media pemeliharaan}

Hasil pemeriksaan kualitas air disajikan pada Tabel 5.4.

Tabel 5.4. Hasil Pemeriksaan Kualitas Air Selama Pemeliharaan 30 Hari

\begin{tabular}{|l|l|l|l|l|l|l|l|}
\hline N0 & Perlakuan & \multicolumn{7}{|c|}{ Paramater } \\
\cline { 3 - 8 } & $\begin{array}{c}\text { Suhu } \\
\left({ }^{\circ} \mathrm{C}\right)\end{array}$ & $\mathrm{pH}$ & $\begin{array}{c}\mathrm{D} 0 \\
(\mathrm{ppm})\end{array}$ & $\begin{array}{c}\mathrm{NH}_{3} \\
(\mathrm{ppm})\end{array}$ & $\mathrm{N} 02$ & $\mathrm{~N} 03$ \\
\hline 1. & $\mathrm{~K} 1$ & 28 & 8,00 & 5 & 0 & 0 & 0 \\
\hline 2 & $\mathrm{~K} 2$ & 28 & 7,6 & 5 & 0,05 & 0,02 & 0 \\
\hline 3. & $\mathrm{~K} 3$ & 28 & 7,6 & 5 & 0,05 & 0,02 & 0 \\
\hline
\end{tabular}

Tabel 5.4. menunjukkan bahwa selama penelitian kualitas air dalam keadaan yang optimal untuk pertumnuhan ikan mas, sehingga tidak mempengaruhi perlakuan penelitian

\subsection{Pembahasan}

Gambaran Darah Putih (Differensial leukosit) merupakan indikator ada tidaknya respon imun dari ikan mas sebagai perlakuan, yang memiliki sistem pertahanan tubuh untuk melawan berbagai macam penyakit. Apabila terjadi perubahan jumlah dan jenis leukosit dapat dijadikan tanda bahwa adanya infeksi penyakit atau faktor lain. Leukosit yang digolongkan dalam limfosit, monosit, heterofil, eosinofil dan basofil merupakan salah satu komponen darah yang berfungsi sebagai pertahanan tubuh spesifik yang akan menetralisir dan memusnahkan patogen melalui proses fagositosis. Tabel 5.1 menunjukkan bahwa persentase limfosit tertinggi pada perlakuan K2 (ikan mas dipapar dengan protein spora Myxoboluskoi) yaitu sebesar 77,6\%.Hal ini lebih tinggi jika dibandingkan dengan persentase pada perlakuan K1 dan K2 yang sama-sama tidak dipapar protein spora, yaitu sebesar 57,8 dan $61,5 \%$. Dilihat dari besarnya persentase limfosit dari ke tiga perlakuan, maka persentase limfosit ikan mas yang dipapar protein spora meningkat hingga melebihi batas kisaran normal .

Peningkatan jumlah limfosit pada ikan mas ini kemungkinan disebabkan karena adanya infeksi dari penyakit yang dalam hal ini adalah Myxobolus koi dan kemungkan juga oleh patogen lain. Infeksi dengan spora $M$. koi merupakan tanggapan sistem pertahanan tubuh ikan atas masuknya patogen. Hal ini sesuai dengan pendapat Bastiawan dkk (2001), limfosit berfungsi sebagai penghasil antibodi untuk kekebalan tubuh dari gangguan penyakit. Pada dasarnya sel limfosit terdiri dari dua populasi yaitu sel B dan sel T. Sel B mempunyai kemampuan untuk bertransformasi menjadi sel plasma yaitu sel yang memproduksi antibodi. Sel $\mathrm{T}$ sangat berperan dalam kekebalan berperantara sel (sel $\mathrm{T}$ sitotoksik) dan mengontrol respons imun (sel T supresor) (Kresno 2001). Setelah terjadi pengikatan antigen dengan reseptor antigen sel limfosit, maka sel limfosit akan membelah dan berdiferensiasi menjadi sel efektor dan sel memori (Tizard 1988).

Dilihat dari gambara monosit, maka persentase monosit pada semua perlakuan (K1, K2 dan K3) berada diatas normal, yang terendah terjadi pada perlakuan K3 yaitu $11,6 \%$. Monosit ini akan memfagositosis spora M. koi yang masuk dalam tubuh ikan mas. Hal ini sesuai dengan pendapat bahwa monosit bersama dengan makrofag akan memfagosit agen penyebab penyakit yang masuk dalam tubuh. Bastiawan dkk (2001) menjelaskan, monosit berfungsi sebagai fagosit terhadap benda-benda asing yang berperan sebagai agen penyakit.

Jumlah heterofil yang tertinggi juga terjadi pada ikan mas pada perlakuan K2 yaitu 14,4\% dan melebihi kisaran normal. Akan tetapi heterofil ini terun pada perlakuan K3 
dan K1. Hal ini disebabkan adanya kenaikan pada limfosit dan monosit sehingga heterofil menurun. Selain itu heterofil tidak terlalu berperan dalam merespon infeksi yang diakibatkan oleh parasit. Heterofil lebih banyak berperan pada infeksi yang diakibatkan oleh bakteri.

Jumlah eosinofil menunjukkan persentase tertinggi pada perlakuan K3 yaitu sebesar 9,2\% lebih tinggi jika dibandinghkan dengan perlakuan $\mathrm{K} 1$ sebesar $6,8 \%$ Hal ini disebabkan kemungkinan terjadinya infeksi Myxobolus koi yang dapat meningkatkan jumlah eosinofil pada darah ikan. Hal ini sesuai dengan pendapat Tizard (1988) yang menyatakan bahwa eosinofil merupakan salah satu sel pertahanan tubuh yang dominan di dalam darah dan akan meningkat tajam jumlahnya bila terjadi infeksi penyakit parasiter.

Hasil penelitian terhadap persentase basofil menunjukkan persentase yang terendah terjadi pada perlakuan $\mathrm{K} 3(0,2 \%)$ dan diikuti dengan $\mathrm{K} 2$ dan $\mathrm{K} 1$, yaitu 0,4 dan 0,9\%, yang semuanya menunjukkan persentase yang sangat rendah. Hal ini sesuai dengan pendapat dari Affandi dan Tang (2002) menyatakan bahwa persentase basofil di dalam darah ikan berkisar antara 0.17-0.194\%.

Hasil pemeriksaan terhadap infeksi parasit Myxobolus koi menunjukkan bahwa infestasi tertinggi terjadi pada ikan mas yang tidak dipapar protein spora dan dipelihara pada media air dari kolam pemeliharaan di Mojokerta (K3) yaitu sebanyak 16 ekor $(53,33 \%)$. Hal ini disebabkan karena ikan mas pada perlakuan K\# tidak dipapar protein spora dan media air yang digunakan kemungkinan sudah terdapat Myxobolus koi dari asalnya., yang pada saat digunakan parasit masih berada pada stadia aktinospora. Menurut Lom and Dicova (1996) menyatakan bahwa stadia infektif dari Myxobolus koi adalah stadia aktinospora yang berada di perairan. Kemudian adanya infestasi parasit Myxobolus koi pada ikan mas yang tidak dipapar protein dan dipelihara pada air yang sudah disterilkan (perlakuan K1), ini kemungkinan disebabkan ikan yang digunakan sudah terinfestasi sejak diambil dari tempat pengambilan dan belum terlihat adanya gejala klinis, sehingga dimasukkan dalam kelompok ikan yang sehat. Infestasi terendah terjadi pada kelompok ikan mas yang dipapar dengan protein spora yaitu hanya 5 ekor (30\%), hal ini disebabkan karen protein spora yang masuk ke dalam tubuh ikan mampu menstimulasi aktivitas sel imun pada ikan dan juga dapat digunakan sebagai bahan pengembangan imunostimulan yang dapat meningkatkan aktivitas sel-sel pertahanan tubuh ikan terhadap Myxobolus koi. Ketika protein spora masuk ke dalam tubuh ikan, maka akan dipresentasikan oleh MHC, kemudian ditangkap oleh reseptor pada sel $\mathrm{T}$ helper (2), dan sel $\mathrm{T}$ helper (2) akan mensekresikan sitokin yaitu IL-2, IL- 4, dan IL-6 sehingga meningkatkan jumlah limfosit dalam darah yang bertujuan untuk diferensiasi dan proliferasi sel B, diferensiasi sel B menghasilkan sel plasma dan sel memori yang dapat mengikat protein spora dan memudahkan proses fagositosis dan akanmenyebabkan menurunnya infestasi parasit Myxobolus koi.

Tabel 5.1. juga menunjukkan bahwa kelulushidupan tertinggi terjadi pada ikan mas pada perlakuan $\mathrm{K} 2$ yaitu yang dipapar protein spora, yaitu sebesar 90\%, sedang yang terendah terjadi pada ikan mas perlakuan K3 yaitu 53,33\%. Tingginya tingkat kjelulushidupan ini disebabkan karena protein spora Myxobolus koi sebagai kandidat imunostimulan dapat dapat memberikan proteksi atau perlindungan yang tinggi ikan mas, disamping karena adanya penurunan infestasi parasit seperti telah dijelakan di atas.

Berdasarkan hasil pengukuran kualitas air suhu, $\mathrm{pH}$ dan oksigen terlarut pada media pemeliharaan seperti yang tertera pada Tabel 5.4 menunjukkan bahwa kualitas air media pemeliharaan masih dalam kondisi normal, sehingga dapat mendukung kelulushidupan ikan. Hal ini sesuai dengan pendapat Amri dan Khoiruman (2002) bahwa ikan koi dapat hidup pada kisaran suhu $8-30{ }^{\circ} \mathrm{C}$. Kadar ammonia $\left(\mathrm{NH}_{3}\right)$ sebelum dan sesudah perlakuan menunjukkan perbedaan dimana ammonia sebelum perlakuan sebesar $0,05 \mathrm{ppm}$.

\section{KESIMPULAN DAN SARAN}

\subsection{Kesimpulan}

Kesimpulan yang dapat diambil dari penelitian ini adalah sebagai berikut :

1) Gambaran darah (differensial leukosit) ikan mas yang dipapar protein spora Myxobolus koi dan dipelihara pada media air dari kolam pemeliharaan dari Mojokerto terjadi peningkatan lymposit yang cenderung tinggi, 
yang berarti terdapat peningkatan respon imun.

2) Terjadinya peningkatan respon imun menyebabkan terjadinya penurunan infestasi Myxobolus koi pada ikan mas yang dipapar protein spora dan dipelihara pada media air yang diambil dari kolam pemeliharaan ikan di Mojokerto.

3) Terjadinya peningkatan respon imun menyebabkan adanya peningkatkan kelulushidupan (SR) ikan mas yang dipapar protein spora Myxobulus koi dan dipelihara pada media air yang diambil dari kolam pemeliharaan ikan di Mojokerto.

\subsection{Saran}

Saran yang dapat diajukan dari hasil penelitian ini adalah perlu adanya penelitian tentang aplikasi pemaparan protein spora melalui pakan sehingga bisa diberikan setiap minggu (14 hari), untuk menjaga respon imun ikan, karena pada hari ke 15 respon imun sudah mulai menurun.

\section{DAFTAR PUSTAKA}

Alejo, A and Tafalla, C., 2011. Chemokines in teleost fish species. Dev. Comp. Immunol. 35: 1215 - 1222.

Amos WB, Routledge LM, and Yew FF, 1975. Calcium-binding proteins in a vorticellid contractile organelle. Cell Sci J, 19 (1) : 203-213.

Anugrahi T, 2013. Efektifitas Daun Ketepeng Cina untuk Penanggulangan Myxobolisis pada Ikan Mas (Cyprinus carpi Linn), Fakultas Perikanan dan Kelautan, Universitas Airlangga. Surabaya.

Anshary, H. 2008. Modul Pembelajaran Berbasis Student Center Learning (SCL) Mata Kuliah Parasitologi Ikan. Jurusan Perikanan Fakultas Perikanan dan Ilmu Kelautan Universitas Hassanudin. Makasar. Hal 126.
Irianto, A. 2005. Patologi Ikan Teleostei. Gajah Mada University Press, Yogyakarta. hal 243.

Ariaty L. 1991. Morfologi Darah Ikan Mas (Cyprinus carpio Linn) Nila Merah (Orechromis sp) dan Lele Dumbo (Clarias gariepinus) dari Sukabumi. [skripsi]. Bogor. Fakultas Perikanan dan Ilmu Kelautan, Institut Pertanian Bogor.

Badan Karantina Ikan, Pengendalian Mutu dan Keamanan Hasil Perikanan. 2011. Pedoman Penetapan Hama dan Penyakit Ikan Karantina. Kementrian Kelautan dan Perikanan. Jakarta. Hal $25-27$.

Baratawidjaja. 1996. Immunologi Dasar. Fakultas Kedokteran Universitas Indonesia. Gaya Baru. Jakarta. Hal 12.

Brunk, C.F., 1999. Ciliates display promise for foreign gene expression, Nature AmericaInc, ${ }^{*}$ http://biotech.nature.com.

Clark, T.G., Tian-Long Lin and H.W. Dickerson, 1996. Surface antigen cross-linking triggers forced exit of a protozoan parasite from its host, Proc. Natl. Acad. Sci. USA, Vol. 93, pp.6825 - 6829, June.

Devi, H. L. N. A. 2011. Hubungan Derajat Infestasi Myxobolus koi Terhadap Jumlah Spora Dan Derajat Kerusakan Pada Usus Ikan Mas (Cyprinus carpio L). Skripsi. Budidaya Perairan. Fakultas Perikanan dan Kelautan. Universitas Airlangga. Surabaya. Hal 60.

Dwijayanti, A. A. 2011. Karakterisasi protein nodul pada insang ikan mas (Cyprinus carpio) akibat infestasi Myxobolus sp dengan metode SDS-PAGE. Skripsi. Fakultas Perikanan dan Kelautan Universitas Airlangga. Hal 2.

Easy R. H., S. C. Johnson and D. K. Cone. 2005. Morphological and molecular comparison of Myxobolus procerus (Kudo, 1934) and M. intramusculi $\mathrm{n}$. sp. (Myxozoa) parasitizing muscles of the trout-perch Percopsis 
omiscomaycus. J.Parasitol 61:115122.

El-Matbouli. M., T. W. Holstein and R. W. Hoffmann. 1998. Determination of nuclear DNA concentration in cells of Myxobolus cerebralis and triactinomyxon spores, the causative agent of whirling disease. J.Parasitol 84: 696-699.

Eszterbauer E., M. Benko, A. Dan and Molnar K. 2001. Identification of fish parasitic Myxobolus (Myxosporea) species using a combined PCR-RFLP method. J.Dis Aquat Org 44:35-39.

Farmer, J. N. 1980. The Protozoan Introduction to Protozoology. The C.V. Mosby Company, St.Louis. 35$36 \mathrm{p}$.

Firmansyah, R. A. F. 2012. Prevalensi Dan Jumlah Nodul Pada Insang Ikan Koi (Cyprinus Carpio) Yang Terinfeksi Myxobolus Di Sentra Budidaya Ikan Koi Kabupaten Blitar-Jawa Timur. Skripsi. Budidaya Perairan. Fakultas Perikanan dan Kelautan. Universitas Airlangga. Surabaya. Hal 42-43.

Guyton Arthur C. and Hall John E. 1999. Buku Ajar Fisiologi Kedokteran. Setiawan I, Tengadi KA, Santoso A, penerjemah: Setiawan I, editor. Jakarta : EGC. Terjemahan dari : Textbook of Medical Physiology. Hal 25-27.

Itabashi T, Mikami K and Asai H, 2003. Characterization of the spasmin I gene in Zoothamnium arbuscula strain Kawagoe (protozoa, eiliophora) and its relation to other spasmins and centris. Res. Microbiol J, 154 ( 5 ) : 361 - 367.

Kudo, R. R., 1977. Protozoology. Fifth Edition. Publisher Ilinois. USA. p.125131.

Kementerian Kelautan dan Perikanan, 2010. Peikanan Budidaya. Jakarta. Hal 1416.

Leff, A.A., T. Yoshinaga and H.W. Dickerson, 1994. Cross immunity in channel catfish, Ictalurus punctatus
(Rafinesque), against two immobilization serotypes of Ichthyopthirus multifiliis (Fouquet), J. of Fish Diseases, Vol. 17, pp. 429 -432 .

Levine ND. 1994. Buku Pelajaran Parasitologi Veteriner. Ashadi, penerjemah. UGM Gadjah Mada Uni Press. Yogyakarta. Terjemahan dari: Textbook of Veterinary Parasitology. Hal 31-32.

Lin, T.L., T.G. Clark and H. Dickerson, 1996. Passive Immunization of Channel Catfish (Ictalurus punctatus) against the Ciliated Protozoan Parasite Ichthyophthirius multifiliis by Use of Murine Monoclonal Antibodies, Infection and Immunity, Oct, pp. $4085-4090$.

Lom, J and I. Dykova. 1992. Protozoan Parasites of Fishes. Developments in Aquaculture and Fisheries Science. 26: $315 \mathrm{p}$.

Lom, J and I. Dykova. 2006. Myxozoan genera: Definition and notes on taxonomy, life cycle, terminology and pathogenic species. J.Folia Parasitol. 53: $35-36$.

Mahasri, G. 2007. Buku Ajar Ilmu Penyakit Protozoa Pada Ikan dan Udang. Universitas Airlangga. Surabaya.

Maki, J.L. and H.W. Dickerson, 2003. Systemic and Cutaneous Mucus Antibody Responses of Channel Catfish Immnunized against the Protozoan Parasite Ichthyophthirius multifiliis, Clinical and Diagnostic Laboratory Immunology, Vol. 10, No. 5, pp.876 - 881 .

Maswan, N. A. Pengujian Efektivitas Dosis Vaksin Dna dan Korelasinya Terhadap Parameter Hematologi Secara Kuantitatif. 2009. Skripsi. Teknologi dan Manajemen Akuakultur. Fakultas Perikanan dan Ilmu kelautan. Institut Pertanian. Bogor. Hal 33.

Mcutcheon SM, NB Mclaughhlin and HE Buhse Jr, 2002. Characterization of Cytoskeletal, Calcium-Binding 
Proteins in Vorticella convallaria, Eukaryot Microbiol J.

Moriyama Y, H Okamoto and H Asai, 1999. Rubber-Like Elasticity and Volume Changes in the Isolated Spasmoneme of Giant Zoothamnium $s p$. under $\mathrm{Ca} 2+-$ Induced Contraction, Biophys J, 76 (2) : 993-1000.

Nazir, M. 2011. Metode Penelitian. Ghalia Indonesia. Bogor. hal. 63-64,124.

Preer, J.R, Jr., 1986. In the molekcular biology of ciliated protozoa, ed. Gall, J.G (Akademic London). Pp. 301-339.

Pylawka, S and Buhse, Jr HE, 2003. Protein Synthesis and Telotroch Formation in Vorticella convallaria, Eukaryot Microbiol J, 198 : 45 - 52

Randelli, E., F. Buonocore and G. Scapigliati. 2008. Cell markers and determinants in fish immunology. J.Fish Shell Immuno. 25: 326-340.

Robert, J. R. 1989. Fish Pathology Second Edition. Bailliere Tindall. London. 64 p.
Routledge LM, $1978 . \quad$ Calcium-binding proteins in the Vorticellid spasmoneme : Extraction and Characterization by Gel Electrophoresis,, Cell Biology J, 77 : 358-370.

Randelli, E., Buonocore. F, and Scapigliati. G., 2008. Cell markers and determinants in fish immunology. J. Fish \& Shellfish Immunology, 25:326-340.

Sommerset I, Krossøy B, Biering E, Frost P. 2005. Vaccines for fish in aquaculture. Exp Rev Vac. 4: 89-101.

Steel R. G and Torrie J. H. 1993. Prinsip Prosedur Statistika, Terjemahan oleh Bambang Sumantri. Gramedia. Jakarta. Hal 425-478.

Stoskopf, M. K. 1993. Fish Medicine. Clinical Pathology of Carp, Goldfish and Koi. Mexico. 882: 54-56.
Stoskopf, M. K and Michael, W.B. 1992. Fish Medicine. Saunders Company, Philadelphia, PA. 11 p.

NACA. 1991. Fish Health Management. In : Asia Pacific report on a Regional Study and Workshop on Fish Diseases and Fish Health Management, ADB Agriculture Department Report Series No.1 Network of Aquaculture Center in Asia-Pacific, Bangkok. 627 pp.

Sugianti, B., R. C. Tarumingkeng, Z. Coto dan Hardjanto. 2005. Pemanfaatan Tumbuhan Obat Tradisional Dalam Pengendalian Penyakit Ikan. Makalah Pribadi Falsafah Sains (PPS-702). Program Pasca Sarjana. Institut Pertanian Bogor. Hal 7-8.

Titis, C. D., W. S. D. Nugroho, D. Dudung, H. Nurul dan Sumayani. 2009. Laporan Uji Coba Identifikasi dan Penentuan Derajat Kerusakan akibat Infeksi Myxobolus koi pada Ikan Mas. Balai Karantina Ikan Kelas II. Semarang. Hal 66.

Tizard I. 1988. Pengantar Imunologi Veteriner. Ed ke-2. Partodirejo M, Hardjosworo S, penerjemah; Surabaya: Airlangga University Press. Terjemahan dari: An Introduction to Veterinary Immunology.

Wijanarko, P. Y. 2011. Hubungan Jumlah Spora Terhadap Jumlah dan Ukuran Nodul Myxobolus koi Yang Menyerang Ikan Mas. Skripsi. Budidaya Perairan. Fakultas Perikanan dan Kelautan. Universitas Airlangga. Surabaya. Hal 15.

Wang, Xuting and H.W. Dickerson. 2002. Surface Immobilization Antigen of the Parasitic Ciliate Ichthyophthirius multifiliis Elicits Protective Immunity in Channel Catfish (Ictalurus punctatus), Clinical and Diagnostic Laboratory Immunology, January, Vol. 9, No. 1, p. $178-181$, Athens, Georgia.

Woro, A.R., Gunanti, M. dan Lucia, T.S., 
Jurnal Biosains Pascasarjana Vol. 19 (2017) pp

(C) (2017) Sekolah Pascasarjana Universitas Airlangga,

2015. Efektivitas Vaksinasi Crude

dan Soluble Protein Spora

Myxobolus koi terhadap tingkat

kerusakan usus ikan koi (cyprinus

carpio koi). Jurnal Ilmu Perikanan

dan Kelautan. April, Vol 2. No.2.

Hal. 12-17

Yuasa, K., Panigoro, N., Bahnan, M., dan Khiidin., B. E. 2003. Panduan Diagnostik Penyakit Ikan. Teknik Diagnosa Penyakit Ikan Budidaya Air Tawar. Balai Budidaya Tawar Jambi.

Yusuf, M. 2015. Analisis Respons Imun Ikan

Koi (cyprinus carpio koi) Yang Divaksin Dengan Whole Protein Spora Myxobolus koi Sebagai Kandidat Vaksin Myxobolusis. Tesis. Sekolah Pascasarjana, Universitas Airlangga. Surabaya. 64 Halaman. 